\title{
Politics and health
}

\section{Carme Borrell, Albert Espelt, Maica Rodríguez-Sanz, Vicente Navarro}

\section{Effect of politics and policies on socioeconomic health inequalities}

$\mathrm{T}$ he amount of scientific literature on social inequalities in health has increased exponentially in recent years. However, the effect of politics and policies on health and on social inequalities in health has rarely been studied. Navarro et $a l^{12}$ proposed a multidimensional conceptual framework that has been used to understand the relationship between politics and health outcomes (fig 1). It is a schematic attempt to show how politics (expressed in terms of electoral behaviour and trade union characteristics) is related to expansion of the welfare state, in turn reflecting the degree to which societies take care of their citizens, ${ }^{3}$ and labour market policies. The welfare state and labour market policies have an effect on income and social inequalities in the population. As fig 1 shows, all these policies and factors are related to health and inequalities in health.

Several authors have described typologies of welfare regimes in wealthy countries of the Organisation for Economic Cooperation and Development. ${ }^{45}$ Navarro et $a^{16}$ have considered four types of countries based on the typology of Huber and Stephens. ${ }^{5}$ First, social democratic countries (Sweden, Norway, Finland, Denmark and Austria) have been governed (either alone or as the major party in a coalition) by social democratic parties for long periods of time during the second part of the 20th century and where unions are strong. These countries are characterised by the universality of benefits, a large social public expenditure (including healthcare), extensive welfare with generous entitlements, a heavy emphasis on public provision of social services and on redistribution through the tax and transfer system. The participation of women in the labour force is high. The redistributive policies imply smaller economic inequalities. Second, Christian democratic countries (Belgium, The Netherlands, Germany, France, Italy and Switzerland) have been governed by parties based on the Christian tradition and have a more heterogeneous class base. They also construct large welfare states, with generous entitlements based mainly on transfers, but a reluctance to provide public social services. The family, and mainly the women, are supposed to provide social services. Therefore, these countries have

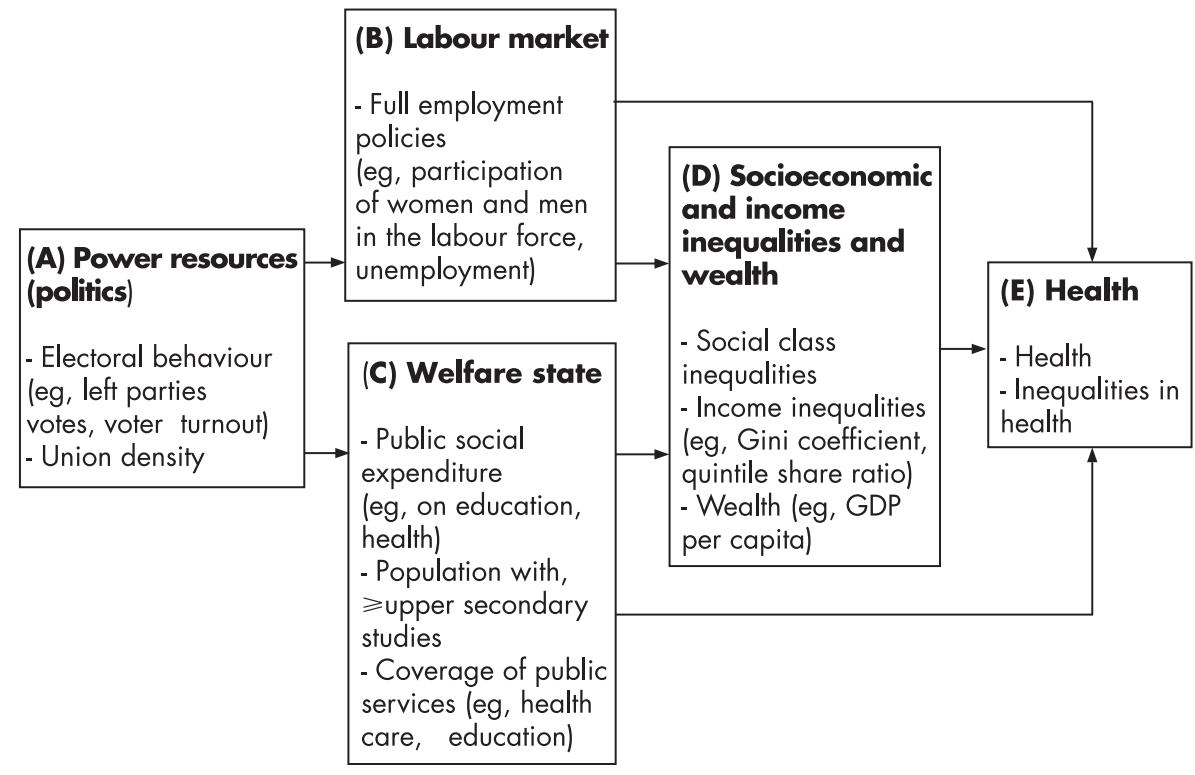

Figure 1 Model showing the relationship between power resources, labour market, welfare state, socioeconomic inequalities and health outcomes (some examples of variables are also shown). Source: Navarro et al.' GDP, gross domestic product. low percentages of women in the labour force. Benefits are provided on the basis of workers' rights, but they are not committed to redistribution and low degrees of inequality. Third, liberal countries (the US, Canada, Great Britain and Ireland) have been governed by parties committed to market forces, where the capitalist class is strong and the labour force is not. They have a residual and assistential welfare state, public social expenditures being concentrated on the people who need more. They have low public expenditures on healthcare. The private sector is important in providing welfare services. The degree of income inequality is high. Finally, exdictatorships (Spain, Greece and Portugal) are countries that have been governed by a fascist or dictatorship government for a long period of time in the second part of the 20th century. The fiscal policies were completely regressive and the welfare state was completely undeveloped. Social expenditures were very low. Moreover, these countries were heavily influenced by Catholic teachings that relied on women for the care of family members, and therefore the participation of women in the labour force was low. In the last few years of the 20th century, these countries achieved democracy and experienced an improvement in social expenditure, but even today they have still not caught up with other developed countries.

The hypothesis behind the conceptual model shown in fig $l$ is that the social democratic countries are more committed to the expansion of the welfare state, full employment policies and a higher percentage of women in the labour force, and therefore have less social and income inequalities, better health outcomes and less inequalities in health. The specific mechanisms of how social democratic countries influence health and health inequalities could be as follows: ${ }^{7}$

(a) Strong labour movements: If labour movements are strong, working conditions will probably be more favourable. It has been shown previously that working conditions are related to health outcomes: traditional occupational diseases, illness related to physical and chemical exposures, accidents at work, and also lifestyles and psychosocial factors at work have a role in health and diseases. ${ }^{8}$

(b) Public benefits are high and are for everyone (universalism): Moreover, these benefits are offered for the whole life of a person. Benefits directed to the whole population enable investments to be directed to everybody, facilitating access to all public goods (education, healthcare, social care, maternity leave, home care and so on). The benefits of welfare state imply being protected in the face of adverse situations (unemployment, sickness and 
so on), which are related to worse health outcomes. With respect to healthcare, it is worth mentioning that health services financed through taxes are important to permit healthcare for everyone and coverage of the costs of illness. The absence of health coverage has been related to poor health and less utilisation of preventive and curative healthcare services. ${ }^{9}$

(c) Full employment policies and a high percentage of women in the labour force are related to health and well-being, especially women's health: Studies that have compared self-perceived health of women, both in paid work and otherwise, show the protective effect of employment. Income provides women with economic independence and increases their power in the household. Moreover, the job environment can offer opportunities to build self-esteem and confidence in one's decision making, social support and experiences that enhance life satisfaction. ${ }^{10}$

(d) Low socioeconomic and income inequalities: Although there has been debate in recent years, there are many studies showing that income inequalities are related to worse health outcomes. Two main explanations have been offered for how income inequalities affect health: First, psychosocial pathways such as perceptions of place in the social hierarchy, social cohesion and interpersonal trust or psychosocial conditions at work (stress, social support, lack of control) can provide an explanation for the health effects of income inequality. Second, neomaterial pathways: this explanation is based on the importance of material factors such as income, living conditions, lack of resources and investments, these factors being the pathways to poor health. ${ }^{11}$

As stated above, few studies have analysed the effect of politics on health. One of the dependent health-related variables most commonly used in such studies has been infant mortality, ${ }^{2} 2$ mainly for the following reasons: (a) it is sensitive over a short period of time, not needing long lag times to obtain results; (b) it is sensitive to social development; and (c) it is sensitive to political and welfare state conditions. These studies found a relationship between welfare regime and infant mortality, the social democratic countries showing better indicators. However, other health outcomes have also been studied comparing countries with different political traditions. ${ }^{2313}$

Until now, few studies have analysed the effect of politics on socioeconomic health inequalities. Dahl et al tried to assess whether class inequalities in health diminish in welfare state regimes, reviewing the empirical evidence of published comparative studies. However, these studies had not focused on comparing health outcomes of different typologies of countries. They did not conclude that health inequalities are systematically smaller in social democratic countries than in other European countries with different welfare regimes. Similar results were found by Muntaner et $a l^{14}$ on comparing Sweden, UK, and Italy as examples of social democratic, Christian democratic and liberal traditions.

Our group is focused on trying to analyse the effect of the aspects presented in the conceptual model shown in fig 1 on inequalities in health by undertaking several studies within the project Tackling Health Inequalities in Europe (http://mgzlx4.erasmusmc.nl/eurothine/). Therefore, in the near future, we expect to have more evidence on this topic.

$J$ Epidemiol Community Health 2007;61:658659.

doi: 10.1136/jech.2006.059063

\section{Authors' affiliations}

Carme Borrell, Albert Espelt, Maica RodríguezSanz, Agència de Salut Pública de Barcelona, Barcelona, Spain

Vincente Navarro, Universitat Pompeu Fabra, Barcelona, Spain

Correspondence to: $\operatorname{Dr} C$ Borrell, Agència de Salut Pública de Barcelona, Pl Lesseps 1,
Barcelona 08023, Spain;

cborrell@aspb.cat

Competing interests: None declared.

\section{REFERENCES}

1 Navarro V, ed. The political and social contexts of health. Amityville, New York: Baywood Publishing, 2004.

2 Navarro V, Muntaner C, Borrell C, et al. Politics and health outcomes. Lancet 2006;368:1033-7.

3 Coburn D. Beyond the income inequality hypothesis: class, neo-liberalism, and health inequalities. Soc Sci Med 2004;58:41-56.

4 Esping-Andersen G. The three worlds of welfare capitalism. Princeton, NJ: Princeton University Press, 1998.

5 Huber E, Stephens J. Development and crisis of the welfare state. Chicago: The University of Chicago Press, 2001.

6 Navarro V, Shi L. The political context of social inequalities and health. Soc Sci Med 2001;52:481-91.

7 Dahl E, Fritzell J, Lahelma E, et al. Welfare state regimes and health inequalities. In: Siegrist J, Marmot $M$, eds. Social inequalities in health. New evidence and policy implications. Oxford: Oxford University Press, 2006:193-222.

8 Marmot M, Siegrist J, Theorell T, et al. Health and the psychosocial environment at work. In: Marmot M, Wilkinson R, eds. Social determinants of health. Oxford: Oxford University Press, 1999:105-31.

9 Hadley J. Sicker and poorer. The consequences of being uninsured: a review of the research on the relationship between health insurance, medical care use, health, work, income, Med Care Res Rev 2003;60(Suppl):3S-75S.

10 Artazcoz L, Borrell C, Cortès I, et al. Occupational epidemiology and work-related inequalities in health: a gender perspective for two complementary approaches to work and health research. J Epidemiol Community Health. In press.

11 Lynch JW, Davey-Smith G, Kaplan GA, et al. Income inequality and mortality: importance to health of individual income, psychosocial environment, or material conditions. BMJ 2000;320:1200-4.

12 Chung H, Muntaner C. Welfare state matters: a typological multilevel analysis of wealthy countries. Health Policy 2007;80:328-39.

13 Raphael D, Bryant T. The welfare state as a determinant of women's health: support for women's quality of life in Canada and four comparison nations. Health Policy 2004;68:63-79.

14 Muntaner C, Borrell C, Kunst A, et al. Social class inequalities in health. Does welfare state regime matter? In: Raphael D, Bryant T, Rioux M, eds, Staying alive. Critical prespectives on health, illness and health care. Toronto: Canadian Scholars' Press, 2006;139-58. 